\title{
A Prospective Study of Medico-Legal Aspect of Permanent Infirmity Cases Examined at Forensic Medicine Authority- Cairo Department, Egypt
}

\author{
Ahmed S. Hafez ${ }^{1}$; Ibrahim S. Elgendy ${ }^{2}$; Ibrahim S.A. Zamzam² Nermeen A. Hassan $^{2}$; Nagah \\ E M Ali ${ }^{2}$ and Abdelmonem G. Madboly ${ }^{2}$ \\ ${ }^{1}$ Medico-legal Examiner, Forensic Medicine Authority - Cairo Department, Ministry of Justice, \\ Egypt \\ ${ }^{2}$ Department of Forensic Medicine \& Clinical Toxicology, Faculty of Medicine, Benha University, \\ Egypt
}

\section{Corresponding Author:}

Abdelmonem G. Madboly; Department of Forensic Medicine and Clinical Toxicology, Faculty of Medicine, Benha University, Egypt.

Email: abdelmonem.algohari@fmed.bu.edu.eg

\begin{abstract}
Permanent infirmity is an important medico-legal issue. Objectives: this prospective study aimed to assess the pattern and methods used in diagnosis and follow up of permanent infirmity cases referred to Cairo Department of Forensic Medicine, Ministry of Justice, Egypt, as well as, to compare between the national and international guidelines used to assess permanent infirmity. Methodology: only established permanent infirmity cases were studied as regard the demographic and medico-legal data, physical examination, and investigations done to the victims. Results: the incidence of established permanent infirmity cases during the period of the study was $7.2 \%$ (150 cases). Most of cases were males of age group 21-40 years, and manual workers. Most of injuries resulted from blunt trauma due to road traffic accidents. The most common investigation done was x-ray; with the majority of cases revealed fractures and amputations of bones of both extremities. The number of permanent infirmities exceeded that of examined cases as some cases sustained more than one injury. Conclusion: limitation of movements represented the highest percentage of the resulted permanent infirmities followed by amputations. The percentages of some infirmities are equal or near equal, and others showed some differences, meanwhile some infirmities were evaluated in the Florida schedule but not in the Egyptian schedule.
\end{abstract}

Keywords: Prospective Study, Medico-legal, Permanent Infirmity, Forensic Medicine Authority, Cairo.

\section{INTRODUCTION}

Permanent infirmity or disfigurement is an important legal as well as medical issue. It is defined as an irremediable functional restriction (loss of a function of an organ) or an irreversible deprivation (loss of a functioning organ) resulted from a physical or mental damage that disables a person to conduct his/her daily activities (Abd ElHady et al., 2013).
Infirmity may be temporary or permanent; temporary infirmity is supposed when the progress of an injury not arrived at its ultimate possible degree of amelioration within six months. Meanwhile, permanent infirmity is an irreversible condition of body impairment (Phoon et al., 1996).

A permanent infirmity could be resulted by traffic accidents, different types 
of assaults, torture or occupational mishaps, but traffic accidents are the most common cause of permanent infirmity or disability (Singh et al., 2014).

Permanent infirmity (physical and/or mental) is considered a lifelong burden, as it deteriorates the quality of life, and destroys the fruitful work years of the victim (Collins, 1991 and Abd El-Hady et al., 2013).

The previous studies of permanent infirmity cases carried out in Egypt did not compare between the national and international guidelines used to assess the degree of permanent infirmity, as well as they did not cover all patterns of permanent infirmity; for example: Zanaty et al. (2005) studied cases of permanent infirmity due to traffic accidents; Haiba et al. (2017) studied cases of permanent infirmity due to occupational injuries, and Ghaleb et al. (2018) studied permanent infirmity cases due to orthopedic injuries.

The current study will cover all patterns of permanent infirmity and it also, will compare between some of the national and international guidelines used to assess permanent infirmity. It is important from the medico-legal point of view to study the patterns \& causes of permanent infirmity.

\section{AIM OF THE WORK}

This work will study the pattern of permanent infirmity cases referred to Cairo Department of Forensic Medicine in the period from the first of May 2016 to the end of November 2016; to assess the different methods used in diagnosis and follow up of permanent infirmity cases in an attempt to compensate cases of permanent infirmity appropriately, as well as to compare between national and international guidelines (Florida Uniform Permanent Impairment Rating Schedule1996) used to assess permanent infirmity.

\section{SUBJECTS AND METHODS}

\section{Subjects:}

This is a prospective study- in the period from the first of May 2016 to the end of November 2016- that was carried out on cases of permanent infirmity referred to Forensic Medicine Authority - Cairo Forensic Department, Ministry of Justice, Egypt.

\section{Inclusion criteria:}

Only closed cases were included in this work, i.e., cases diagnosed as established permanent infirmity after complete investigations.

\section{Exclusion criteria:}

Any open permanent infirmity cases were excluded, as in cases which were recently referred after a short period of injury, and need to be re-examined after complete cure, e.g., injuries with stitches, injuries associated with inflammation, fractures with casts, eye injuries associated with edema or corneal stitches) and cases which will undergo any surgical interference or need any medical aids.

An informed consent was obtained from each participant in the current study. A written permission was also obtained from the Forensic Medicine AuthorityCairo Forensic Department to conduct this study.

The study protocol was approved by the Local Ethical Committee of Benha Faculty of Medicine and the confidentiality of the records was considered.

\section{Methods:}

A specially designed data sheet was used to prospectively examine the permanent infirmity cases referred to Forensic Medicine Authority - Cairo Forensic Department.

The following parameters were studied:

1- Incidence of permanent infirmity cases in relation to total cases examined during the period of the study. 
2 - Demographic data: victim's age, gender, residence, marital status, educational level and occupation.

3- Medico-legal data: circumstances (assault, torture, occupational hazards, medical malpractice or traffic accidents), crime scene, manner of injury, weapon used, type of trauma and resulted injury.

4- Physical examination: part of body involved (site of trauma), type of permanent infirmity, percentage of disability.

5- Investigational data: $X-$ ray, computed tomography, ultra-sound, ophthalmoscope, magnetic resonance imaging, electromyography and nerve conduction study.

6- A comparison between the national and the international permanent infirmity rating guides; (Florida Uniform Permanent Impairment Rating Schedule1996) was made (in some relevant points).

\section{Statistical Analysis:}

The collected data were organized and statistically studied using the SPSS software statistical computer package version (21). Data were presented as number and percent distribution (Dawson and Trapp, 1994).

\section{RESULTS}

\section{Incidence:}

All cases referred to Forensic Medicine authority - Cairo Forensic Department during the period from the first of May 2016 to the end of November 2016 were 2075 cases. The incidence of established permanent infirmity cases during the period of the study was $7.2 \%$ (150 cases).

\section{Demographic data:}

\section{1-Age:}

The most common age group was (2130) years constituted 45 cases $(30 \%)$. Followed by the age group (31- 40)years constituted 34 cases $(22.7 \%)$, the age group $41-50$ constituted 26 cases $(17.3 \%)$, the age group of more than 50 years constituted 26 cases $(17.3 \%)$ and the least age group involved was $(\leq 10)$ years constituted only four cases $(2.7 \%)$.

\section{2-Gender:}

Out of 150 cases enrolled in the study, 125 cases $(83.4 \%)$ were males and 25 cases $(16.6 \%)$ were females.

\section{3-Residence:}

Cases from rural areas constituted 83 cases (55. 3\%) and cases from urban areas constituted 67 cases $(44.7 \%)$.

\section{4-Marital status:}

Married cases represented the majority $(64.7 \%)$ of cases, while single victims represented $30 \%$, widowed cases represented $4.6 \%$ and divorced ones were only $0.7 \%$ of total cases.

\section{5-Educational level:}

Out of 150 cases enrolled in the study, the highest percentage of educational level was for persons have secondary school certificate [59 cases (39.3\%)] followed by illiterate persons [47 cases $(31.3 \%)]$ and the least percentage was for preschool [one case $(0.6 \%)$ ].

\section{6-Occupation:}

Manual workers constituted 61cases $(40.7 \%)$ followed by civil employees 22cases (14.7\%), students 17cases (11. $3 \%$ ), drivers 15 cases $(10 \%)$. Farmers and housewives had the same percentage $7.3 \%$ (11 cases). The least percentage was for soldiers $0.7 \%$ (one case).

\section{Medico-legal data:}

\section{1- Circumstances:}

The study represented that 71 cases (47.3\%) had permanent infirmity due to road traffic accidents, 43 cases $(28.7 \%)$ due to quarrels, 11cases (7.3\%) due to domestic violence, nine cases $(6 \%)$ due to medical malpractice, nine cases $(6 \%)$ due to assault for stealing, six cases $(4 \%)$ due to occupational hazards and one case $(0.7 \%)$ due to torture.

\section{2- Manner of injury:}


The study demonstrated that 77 cases (51.3\%) of permanent infirmity occurred accidentally, 64 cases $(42.7 \%)$ occurred homicidally and nine cases $(6 \%)$ occurred due to medical malpractice. In other words the traumatic permanent infirmity cases were 141 cases and permanent infirmity cases due to malpractice were 9 cases.

\section{3- Scene of crime:}

Majority of cases of permanent infirmity occurred in the street 120 cases $(80 \%)$, nine cases $(6 \%)$ occurred in hospitals. Injuries at home constituted 11 cases $(7.3 \%)$. Injuries at work that lead to permanent infirmity constituted nine cases $(6 \%)$. and one case $(0.7 \%)$ occurred in police station.

\section{4- Offender in case of homicidal manner:}

Neighbors are the offender in 27cases $(42.2 \%)$. A family member is the offender in 11 cases $(17.2 \%)$, while a stranger is the offender in nine cases (14.1\%) and a friend is the offender in eight cases (12.5\%). The police officer is the offender in one case (1. $5 \%)$.

\section{5- Type of weapon in traumatic permanent infirmity cases:}

Permanent infirmity cases occurred due to blunt instrument were 98 cases $(69.5 \%)$, 23 cases $(16.3 \%)$ were due to sharp instruments, 13 cases $(9.3 \%)$ were due to firearms, three cases $(2.1 \%)$ were due to fire burn, two cases $(1.4 \%)$ were due to chemical burn and two cases (1.4\%) were due to human bite.

\section{6- Cases of permanent infirmity due to medical malpractice:}

The study demonstrated cases occurred due to medical malpractice where three cases occurred after surgical intervention, two cases occurred after ophthalmic operations, two cases occurred after orthopedic intervention and two cases occurred after gynecological operations.

\section{7- Resulted disability:}

The current study revealed that 61 cases $(40.7 \%)$ of permanent infirmity had limitation of movement of different degrees at a certain site of the body, 17 cases $(11.3 \%)$ had amputations of different degrees in the upper and lower limbs, 15 cases $(10 \%)$ had paralysis of peripheral nerves, 14cases $(9.3 \%)$ had decrease in visual acuity of different degrees, five cases (3.4\%) had loss of area of skull bone, two cases $(1.3 \%)$ had paraplegia. The most common type of permanent infirmity in abdominal injured cases was splenectomy constituted four cases $(2.7 \%)$ followed by surgical hernia in two cases (1.3\%), orchidectomy in two cases (1.3\%)and five cases had hysterectomy, nephrectomy, urine incontinence, fecal incontinence and removal of part of intestine. There were four cases $(2.7 \%)$ of hearing loss of different degrees, three cases $(2 \%)$ of loss of teeth and two cases $(1.3 \%)$ of loss of ear pena. There were 14 cases (9.3) of multiple infirmities.

\section{Physical examination:}

\section{1- Part of the body involved (site of trauma): \\ Injuries of extremities accounted for the majority of permanent infirmity cases during the period of the study, with lower extremities injuries accounted for 52 cases (34.7\%), upper limb injuries accounted for 36 cases (24\%), eye injuries for 15 cases (10\%), head injuries for 13 cases $(8.6 \%)$, and the least percentage for neck and chest injuries each $0.7 \%$ (one case). There were 14 cases $(9.3 \%)$ sustained more than one trauma at different sites of the body.}

\section{2-Type of permanent infirmity:}

Out of 150 cases enrolled in the study, cases of total permanent infirmity contributed for two cases $(1.34 \%)$ examined while cases of partial permanent infirmity represented the vast majority of cases [148 cases $(98.66 \%)]$.

\section{3-Percentages of permanent infirmity:}

The study revealed that $26(17.3 \%)$ cases had a permanent infirmity percentage 
between0-10\%, $39(26 \%)$ cases had a permanent infirmity percentage between $11-20 \%, 31(20.6 \%)$ cases had a permanent infirmity percentage between $21-30 \%, 26$ $(17.3 \%)$ cases had a permanent infirmity percentage between $31-40 \%, 12$ ( $8 \%$ ) cases had a permanent infirmity percentage between $41-60 \%$ and 16 ( $10.6 \%)$ cases had a permanent infirmity percentage between 61-100\%[ Percentages of permanent infirmities according to table No. 2 attached to the decision of the Minister of Social Security No. 137 for the year 1978 on the assessment of the percentage of the permanent infirmity].

\section{Investigational data:}

\section{1-Types of investigations:}

X-ray had done for 79 cases, electromyography and nerve conduction study for 13 cases, ultra-sound for 10 cases, ophthalmoscope for six cases, computed tomography for four cases, hearing tests for three cases and duplex for one case. There were four cases no investigation done for them and 30 cases had more than one investigation.

\section{2-Findings of x-rays:}

Fractures of left tibia internally fixed and accompanied by joint stiffness represent $15 \%$ of cases, amputations of different parts of the bones of the upper limbs represent $13 \%$ of cases, fractures of right tibia internally fixed and accompanied by joint stiffness represent $11 \%$ of cases, fractures of different bones of the upper limbs accompanied by joint stiffness represent $10 \%$ of cases, fractures of left femur internally fixed and accompanied by joint stiffness represent $7 \%$ of cases, amputations of different parts of the bones of the lower limbs represent $7 \%$ of cases, fractures of right femur internally fixed and accompanied by joint stiffness represent $6 \%$ of cases, bone defects of different sizes of skull represent $6 \%$ of cases, fractures of vertebrae fixed by plates and screws represent $3 \%$ of cases and fractures of left zygomatic bone represent $1 \%$ of cases.

\section{3-Findings of ultrasounds:}

Splenectomy is the finding in seven cases $(33.3 \%)$. Loss of left testicle is the finding in two cases $(9.5 \%)$. Removal of ascending colon and part of small intestine, left nephrectomy, hysterectomy, urinary bladder deformity and removal of one ovary each represents a finding in one case $(4.8 \%)$. Ultrasounds done on eyes revealed vitral floats and signs of foreign bodies in three cases $(14.2 \%)$, retinal detachment in two cases $(9.5 \%)$, and lens opacity in two cases $(9.5 \%)$.

\section{4-Findings of electromyography and nerve conduction study:}

Paralysis of left ulnar nerve is found in three cases $(14.3 \%)$, paralysis of right ulnar, median and radial nerves is found in two cases $(9.5 \%)$, paralysis of left ulnar, median and radial nerves is found in two cases (9.5\%), paralysis of left median nerve is found in two cases (9.5\%), paralysis of nerve plexus of right upper limb is found in one case $(4.8 \%)$, loss of innervation of anus is found in one case $(4.8 \%)$, paralysis of left common peroneal nerve is found in two cases $(9.5 \%)$, paralysis of right common peroneal nerve is found in two cases $(9.5 \%)$ and a normal study was found in six cases (28.6\%).

VI. A comparison between the national and the international permanent infirmity rating guides; (Florida Uniform Permanent Impairment Rating Schedule1996):

Some percentages of some infirmities are equal or near equal in the Egyptian schedules and Florida schedule as in: loss of the hand or its benefit $(55 \%-65 \%)$, loss of more than one third of small intestine $(10 \%-30 \%)$ and unilateral nephrectomy (0\%-15\%). There is deference in the percentages of some infirmities in the Egyptian schedules and Florida schedule as in amputation of the lower limb at ankle name of the operation is Syme operation (Frykberg et al., 2007) - which is $45 \%$ in the Egyptian schedules but it is $28 \%$ in Florida schedule and spleenectomy which is 
$35 \%$ in the Egyptian schedules but it is( 0\%- $10 \%$ ) in Florida schedule.

There are some infirmities evaluated in the Florida schedule but not evaluated in the Egyptian schedules as in: colostomy (5 $\%-10 \%$ ), bilateral loss of the fallopian tubes and/or ovaries occurs in premenopausal years (30 \%- 35\%) and absence of mammary gland functions in females $(0 \%-20 \%)$.

Examples of permanent infirmity cases

Case No. 1

(Skull Depressed fracture with loss of bone)

Demographic data:

Victim's age: 32 years

Gender: female

Residence: urban

Marital status: married

Educational level: illiterate

Occupation: housewife

Medico-legal data:

Circumstances: assault (quarrel)

Crime scene: home

Manner of injury: homicidal (domestic violence)

Offender: Family member (husband)

Weapon used: Blunt object may be a stick.

Investigational data: $\mathrm{X}-$ ray, $\mathrm{CT}$

Physical examination:

Part of body involved: head

Type of permanent infirmity: partial

Egyptian evaluation: (40\%)

International evaluation: $(20 \%)$

Case No. 2

(Amputation of right upper limb)

Demographic data:

Victim's age: 45 years

Gender: male

Residence: rural

Marital status: married

Educational level: illiterate

Occupation: farmer
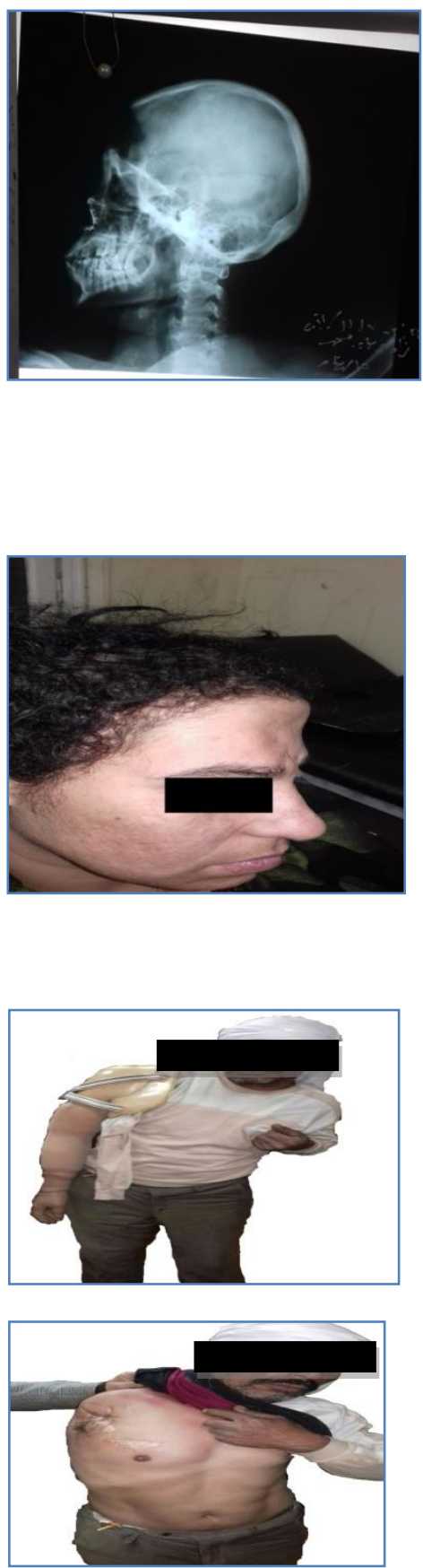
Medico-legal data:

Circumstances: road traffic accident.

Manner of injury: accidental

Weapon used: blunt trauma due to a car accident.

Investigational data: $\mathrm{X}$ - ray

Physical examination:

Part of body involved: right upper limb

Type of permanent infirmity: partial

Egyptian evaluation: (80\%)

International evaluation: $(60 \%)$

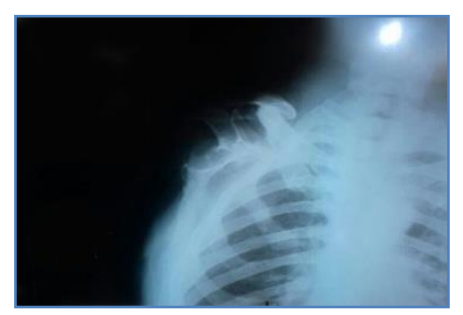

Case No. 3

Demographic data:

(Bilateral loss of vision)

Victim's age: 35 years

Gender: male

Residence: rural

Marital status: married

Educational level: secondary

Occupation: farmer

Medico-legal data:

Circumstances: assault (quarrel)

Crime scene: street

Manner of injury: homicidal

Offender: Neighbor

(Bilateral loss of vision)

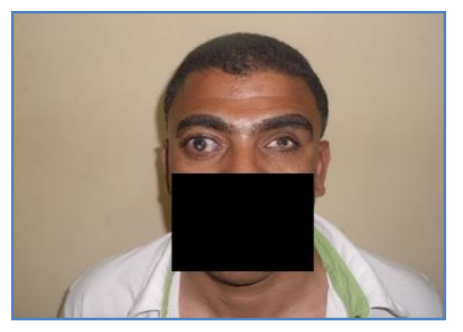

Weapon used: Firearm ( shotgun).

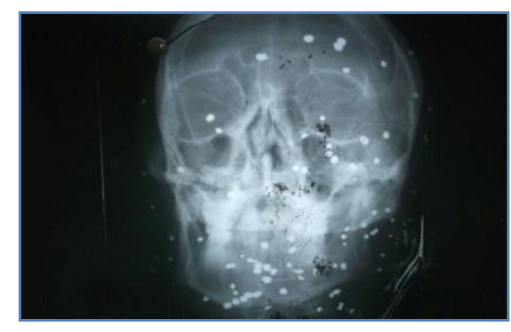

Investigational data:

$\mathrm{X}$ - ray, Ophthalmoscope.

Physical examination:

Part of body involved: head

Type of permanent infirmity: total

Egyptian evaluation: (100\%)

International evaluation: (80\%)

of vision.

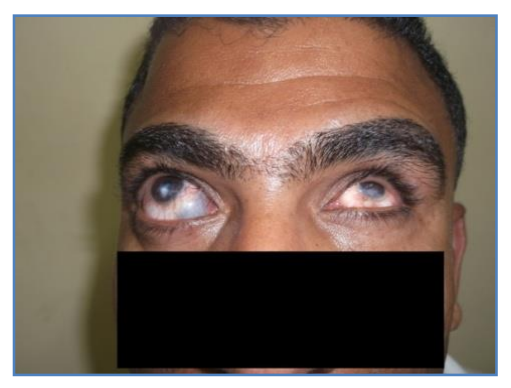

\section{DISCUSSION}

Permanent infirmity is a functional restriction as a result of physical or cosmetically that limits the capability of an individual to carry out his/her daily activities, and that infirmity is predicted to stick on the individual for his/her expected lifetime (Gibofsky et al., 1995). 
In the present study the most common age group among permanent infirmity cases was 21-30 years which represented $30 \%$ of the total cases, followed by the age group 31- 40 years (22. 6\%), and the least age group was $\leq 10$ years which was $2.6 \%$ of cases.

Abd El-Hady et al. (2013) in a retrospective study of permanent infirmity cases at Assiut Medicolegal Department, Egypt, found that the majority of cases were in age group 21-30 years $(43.75 \%)$ followed by age group 31-40 years (25.69\%).

These results could be explained by the fact that the working group populations are more susceptible to the occupational hazards, traffic accidents and quarrels.

The present study found that males with disabling injuries outnumbered females, i.e. male cases represented 83.4 $\%$, while female cases represented only $16.6 \%$ of all studied cases.

Airey et al. (2001) studied the prevalence of disability and handicap among survivors of major traumatic injury in the Yorkshire Health Region-United Kingdom and concluded that males represented $77 \%$ of disability cases resulted from road traffic accidents.

This result reflected that males are more active, aggressive and hence they are more prone to injuries than females.

In the present study residents of rural areas were nearly equal to residents of urban areas who had permanent infirmities and manual workers constituted $34 \%$ of permanent infirmity cases followed by civil employees (13.3 $\%)$ and farmers $(7.3 \%)$.

On the other hand, Abd El-Hady et al. (2013) found that the majority (93\%) of cases came from rural areas and farmers constituted $68.75 \%$ of the studied cases, whereas manual workers represented about $20.83 \%$ of the total cases.

This may be explained by the fact that the present study conducted at Forensic Medicine Authority - Cairo Forensic Department with cases examined from different governorates of Egypt, while Abd El-Hady et al. (2013) conducted his study at Assiut Governorate with most of population from rural areas and the majority of them are farmers.

As regard the educational level of the victims of permanent infirmity; the highest percentage in the current work was for persons who had a secondary school certificate (39. 3\%), and they nearly equal to illiterate persons $(31.3 \%)$, while persons who had university certificate accounted only for $13.3 \%$ of the total studied cases.

Zanaty et al. (2005) studied cases of permanent infirmity attended at Emergency Department, Menoufiya University Hospital, Egypt and reported that about half of the cases $(50.2 \%)$ were illiterate.

This indicates that the level of education has a great influence over the criminal behavior, and it might affect knowledge of safety measures, as illiterate persons and persons who have secondary school certificates are more susceptible to injuries more than who have university certificates.

The present study found that the majority $(47.2 \%)$ of cases had permanent infirmity due to road traffic accidents; $28.6 \%$ due to quarrel, $7.2 \%$ of cases due to domestic violence, $6 \%$ due to assault for stealing, $6 \%$ of cases were due to medical malpractice, $4 \%$ of cases due to occupational hazards and $0.6 \%$ of cases due to torture. 
Ghaleb et al. (2018) reported that motor vehicle accidents represented the main cause of permanent infirmities and constituted about $69.5 \%$ of cases.

WHO (2018) concluded that between 20 and 50 million more people suffer nonfatal road traffic injuries, with many incurring a disability as a result of their injury. Egypt represents the highest country in the world of road traffic accidents rate, and that explained by bad conditions of the roads, over population, lake of experience of drivers and drugs consumption during driving.

The current study found that $6.6 \%$ of cases of permanent infirmity were due to domestic violence and this coincided with Samy et al. (2014) who studied cases of physical and sexual domestic violence arrived at Menoufia University Hospital, Egypt, and found that cases of permanent infirmity due to domestic violence constituted only $2 \%$ of total studied cases.

In the current study, permanent infirmity cases due to torture represented only $0.6 \%$ of cases and this coincided with Ghaleb et al. (2014) who reported in their retrospective study of positive physical torture cases in Cairo, Egypt, that, cases of permanent infirmity due to torture constituted only $0.59 \%$ of total studied cases.

The present study showed that the majority $(80 \%)$ of cases of permanent infirmity occurred in the street; this result was in agreement with Zanaty et al. (2005) who recorded that $53.8 \%$ of permanent infirmity cases occurred in the street. This high percentage occurred because traffic accidents and assault constitute the two main causes of permanent infirmity which occurred mostly in the street.

The current study revealed that 69 , $5 \%$ of cases who had permanent infirmity were due to blunt instrument while sharp instruments constituted $16.31 \%$ of cases and firearm injuries constituted $8.2 \%$ of cases.

This was in agreement with Wasfy et al. (2009) who found that blunt instruments as a cause of injury represented $63.6 \%$ of ophthalmic medicolegal cases in Assiut - Egypt, followed by sharp instrument $(17.8 \%)$ and firearm $(5.7 \%)$.

Also Haiba et al. (2017) studied cases of permanent infirmity due to occupational injuries referred to the Disability Committee of Noqrashi Hospital- Alexandria, Egypt concluded that the most common causative instrument was blunt instrument (82.6\%), followed by machinery injury $(11.4 \%)$ then sharp instrument (3.6\%).

In this study the most common performed investigation was x-ray done for $66.7 \%$ of cases; with the majority of cases revealed fractures and amputations of bones of upper and lower limbs, followed by ultrasound for $10.8 \%$ of cases and electromyography \& nerve conduction study for $10.8 \%$ of cases. This was in agreement with Ghaleb et al. (2018) who reported that X-ray represented the most common investigation done for $85.5 \%$ of cases of permanent infirmity.

This reflected the importance of $\mathrm{X}$ ray in detection the site of fractures, degree of bone healing and to some degree the diagnosis of joint stiffness. Also, X-ray is the most available \& low cost investigation.

The present study revealed that the main findings of electromyography and nerve conduction tests were paralysis of peripheral nerves at different sites found in 15 cases and a normal study was found in six cases.

Weber (1990) stated that nerve conduction and electrophsiological tests 
were very sensitive and accurate methods for detection of the level of neurologic deficit and determining the prognosis.

The current study revealed that spleenectomy was the most common ultrasound finding detected in seven cases $(33.3 \%)$. Damage of left testicle was found in two cases $(9.52 \%)$. Removal of ascending colon and part of small intestine, left nephrectomy, hysterectomy, urinary bladder deformity and removal of one ovary each represent $4.8 \%$ (one case).

Zanaty et al. (2005) reported that all explored cases had internal abdominal injuries and the same findings were diagnosed by ultrasonography.

In the current study, ultrasounds done on eyes revealed vitral floats and signs of foreign bodies in three cases, retinal detachment in two cases, and lens opacity in two cases. Sastry et al. (1993) stated that ultrasonography is useful for evaluation of the globe and for determining the gross anatomy of intraocular tissues. Also it helps in determining whether vitreous or choroidal hemorrhage is present.

In this study the number of permanent infirmities (164 infirmities) exceeded the number of examined cases (150 cases) because some cases sustained more than one injury on different parts of the body.

This coincided with Haiba et al. (2017) who reported that in 1317 studied cases, some of them sustained more than one injury making the total number of injuries among the studied cases 1765 injuries, which resulted in more than one type of permanent infirmities within the same individual.

The present study demonstrated that lower limb injuries accounted for $37.19 \%$ of cases [either lower limb injury alone $(34.66 \%)$ or lower limb injury with another body injury (2.53\%)] of permanent infirmity, meanwhile upper limb injuries accounted for 26. $21 \%$ of cases [either upper limb injury alone (24\%) or upper limb injury with another body injury $(2.21 \%)$ ] and both totally equal about $63.4 \%$ of cases.

These results were in agreement with Collins (1991) who studied impairments in United States in the period from 1985 to 1987 and revealed that $80 \%$ of impairments were in the extremities and back. Rice et al. (1989) stated that extremities are more liable to dangerous injuries as they are more exposed.

This study revealed that limitation of movements represented the highest percentage $(51.82 \%)$ of the resulted permanent infirmities; amputations came in the second degree representing $12.19 \%$ of the resulted permanent infirmities.

This was in agreement with Ghaleb et al. (2018) who reported that limitation of movements represented the highest percentage $(34.5 \%)$ of the resulted permanent infirmities and amputations come in the second degree represented $17 \%$ of the resulted permanent infirmities.

This can be explained by the fact that most of the injuries were due to road traffic accidents and assault by using blunt objects as mentioned above which associated with joints stiffness of different degrees and amputations of limbs of different degrees.

The Florida Uniform Permanent Impairment Rating Schedule (1996) based on the American Medical Association's Guides to the evaluation of permanent impairment; because of the scope, depth, standardized approach, and foundation in science and medical consensus, the guide is used worldwide to estimate adult permanent impairment (Bhattacharya et al., 2010).

The current study performed a comparison between some of the national 
and the international (Florida schedule) permanent infirmity rating guides and revealed that:

- The percentages of some infirmities are equal or near equal in the Egyptian schedules and Florida schedule as in: loss of the hand or its benefit $(55 \%$ $65 \%)$, ankylosis of the elbow joint (30\% $50 \%$ ), complete bilateral loss of olfactory sensation ( $3 \%-5 \%)$, hernias (0\%-30\%), loss of more than third of small intestine $(10 \%-30 \%)$, unilateral nephrectomy (0\%-15\%) and decrease in the vertical opening of the jaw ( $5 \%-20 \%$ ).

- There were some differences in the percentages of some infirmities in the Egyptian schedules and Florida schedule as in:

1. Amputation of the lower limb at ankle - syme operation - which is $45 \%$ in the Egyptian schedules, but it is $28 \%$ in Florida schedule.

2. Unfilled skull defect more than $5 \mathrm{~cm} \times 2 \mathrm{~cm}$ which is $10 \%-20 \%$ in the Egyptian schedules but it is $3 \%-20 \%$ in Florida schedule.

3. Head trauma with headache which is $20 \%$ in the Egyptian schedules, but it is $0 \%$ in Florida schedule.

4. Pelvic trauma with pain and difficulty in walking which is $10 \%-20 \%$ in the Egyptian schedules but it is $0 \%$ in Florida schedule.

5. Complete unilateral loss of which is $35 \%$ in the Egyptian schedules, but it is $24 \%$ in Florida schedule.

6. Complete bilateral loss of vision which is $100 \%$ in the Egyptian schedules, but it is $85 \%$ in Florida schedule.

7. Loss of penis or loss of sexual and renal functions of penis which is $60 \%$ in the Egyptian schedules, but it is $45 \%$ in Florida schedule.

8. Trauma or disease produces bilateral anatomical loss of testes, or there is no detectable seminal or hormonal function of the testes (according to age) which is $30 \%-60 \%$ in the Egyptian schedules but it is $16 \%-20 \%$ in Florida schedule.
9. Spleenectomy which is $35 \%$ in the Egyptian schedules, but it is $0 \%-10 \%$ in Florida schedule.

10. Hepatic cell failure which is $100 \%$ in the Egyptian schedules, but it is $45 \%-75 \%$ in Florida schedule.

There are some infirmities evaluated in the Florida schedule but not evaluated in the Egyptian schedules as in: colostomy $(5 \%-10 \%)$, bilateral loss of the fallopian tubes and/or ovaries occurs in premenopausal years $(30 \%-35 \%)$ and absence of mammary gland functions in females $(0 \%-20 \%)$.

The basic rule on which Florida guide rating impairments is that the person is considered disabled when has a physical or mental impairment that substantially limits one or more of the major life activities (basic activities that the average person in the general population can perform with little or no difficulty, including caring for oneself, manual tasks, hearing, walking, learning, speaking, breathing, working, and reproduction) (The American Medical Association Guide, 1993).

So, we found some percentages had a little values in the Florida guide than in the Egyptian guides because high social care of disabled victims and advanced assistive devices or prosthesis used to enable the disabled individuals to perform the major life activities were available in the United States to some degree more than in our developing country.

\section{CONCLUSION}

The current study summarized the pattern of permanent infirmity cases referred to Cairo Department of Forensic Medicine during the period of study as follows; most of them were males of age group 21-40 years, manual workers, had a secondary school certificates or illiterates persons, due to blunt instrument resulted mainly from road traffic accidents. 
The current study assessed the different methods used in diagnosis and follow up of permanent infirmity cases as follows:

1. Most common investigation done was X-ray; with the majority of cases revealed fractures and amputations of bones of upper and lower limbs, followed by ultrasound and electromyography \& nerve conduction study.

2. The number of permanent infirmities exceeded the number of examined cases as some cases sustained more than one injury on different parts of the body.

3. Limitation of movements represented the highest percentage $(51.82 \%)$ of the resulted permanent infirmities followed by amputations.

The current study compared between some of the national (Egyptian schedule) and international (The Florida Uniform Permanent Impairment Rating Schedule) guidelines used to assess permanent infirmity, and revealed that:

1. The percentages of some infirmities are equal or near equal in the Egyptian schedules and Florida schedule.

2. There were some differences in the percentages of some infirmities in the Egyptian schedules and Florida schedule.

3 . There are some infirmities evaluated in the Florida schedule but not evaluated in the Egyptian schedules.

\section{RECOMMENDATIONS}

1- As the majority of permanent infirmity cases due to motor car accidents, the present study recommends activation and true applications of traffic laws.

2- Improving the level of education as it is an important factor in decreasing the incidence of permanent infirmities.

3- Safety measures at workplaces should be available and its efficiency should be assessed regularly.

4- Periodic revision of the national guides used for rating permanent infirmities to fulfill missing infirmities and continuous updating of these tables for greater scientific accuracy is mandatory.

\section{ACKNOWLEDGMENT}

We would like to express our deep appreciation to our colleges at faculty of medicine, Benha University, and to our colleagues at Forensic Medicine Authority Cairo Forensic Department for their constructive guidance and effective help. http://www.fmed.bu.edu.eg

\section{REFERENCES}

Abd El-Hady, R.H.; Thabet, R.H.; Ghandour, N.M. and Mandor, A.M. (2013): Medico-legal aspects of permanent infirmities as a sequel of different types of injuries (a retrospective study in Assiut Governorate, Egypt). Ain Shams J. Foren. Med. Clin. Toxicol., 20: 9298.

Airey, C.M.; Chell, S.M.; Rigby A.S.; Tennant, A. and Connelly, J.B. (2001): The epidemiology of disability and occupation handicap resulting from major traumatic injury. Disabil. Rehabil., 23(12): 509-515.

American Medical Association (1993): Guides to the evaluation of permanent impairment. Chicago, 4th ed., ch. (1), pp:1-16.

Bhattacharya, J.; Neuhauser, F.; Reville, R.T. and Seabury, S.A. (2010): Evaluating permanent disability ratings using empirical data on earnings losses. J. Risk Insurance, 77 (1): 231-260. doi: 10.1111/j.1539-6975.2009.01343.x

Collins, J. (1991): Impairments due to injuries: United States, 1985-1987. Vital Health Stat., 10 (177): 1-50. 
Dawson, S.B. and Trapp, R. (eds.) (1994): Basic and clinical biostatistics. In: Biostatistics: a foundation for analysis in the health sciences. 2nd ed., Lange Medical Book prentice - Hall International Inc. Ch 4. pp. 201-205.

Frykberg, R.G:; Abraham. S.; Tierney, E.; Hall, J. (2007): Syme amputation for limb salvage: early experience with 26 cases. J. Foot Ankle Surg., 46 (2): 93-100. doi: 10.1053/j.jfas.2006.11.005

Ghaleb, S.S.; Elshabrawy, E.M. and Elkaradawy, M.H. and Nemr, W. N. (2014): Retrospective study of positive physical torture cases in Cairo during (2009 \& 2010). J. Foren. Leg. Med., 24:37-45. doi: 10.1016/j.jflm.2014.03.005. Epub 2014 Mar 29.

Ghaleb, S.S.; Elwahab, H.D.A.; Shehab, A.M. and Hassan S.A.M. (2018): Medico-legal aspects of disabilities due to orthopedic injuries and compensations in Egypt. J. Foren. Leg. Med., 58: 34-40. doi: 10.1016/j.jflm.2018.04.008

Gibofsky, A.; Hirsh, H.A. and Le Blang, T. R. (1995): Impaired and disabled patients. In: Legal Medicine, American Collage of Legal Medicine. $3^{\text {rd }}$ ed., New York, Philadelphia, London, Madried, Mexico. city, Tokyo, Toronto: Mosby. Year Book, Inc., chapter (37), pp: 531-533.

Haiba, M.I.; Sherif, N.A.; Mashally, A.A. and BadrElden, F.M.M. (2017): A medico-legal study of permanent infirmities resulting from occupational injuries in Alexandria Governorate. Master Thesis. Faculty of Medince, Alexandria University.

Phoon, W.H.; Das De, S. and Bose, K. (eds.) (1996): Assessment of disability for compensation. In: Text
Book of Occupational Medicine Practice. World Scientific, Singapore, Chapter (18), pp: 383-399. doi: 10.1142/9789814291088_0018

Rice, D.P.; Mackenzie, E.J. and et al. (1989): Cost of Injury-United States: A Report to Congress, 1989. San Francisco, Institute for Health and Aging, University of California. J.A.M.A., 262 (20): 2803-2804. doi:10.1001/jama.1989.03430200031 006

Samy, M.B.; Naira, F.G.; Amira, M.E. and Fatma, S.K. (2014): A prospective study of some medicolegal aspects of physical and sexual family violence cases at Menoufia University hospital over 2 years. Menouf. Med. J., 27:122-129.

Sastry, S. M.; Paul, B.K.; Bain, L. and Champion, H.R. (1993): Ocular trauma among major trauma victims in a regional trauma center. $J$. Trauma, 34 (2): 223-226.

Singh, R.; Singh, H.K.; Gupta, S.C. and Kumar, Y. (2014): Pattern, severity and circumstances of injuries sustained in road traffic accidents: A tertiary care hospital-based study. Ind. J. Com. Med., 39 (1): 30-34. doi: 10.4103/0970-0218.126353

Wasfy, I.A.; Wasfy, E. I.A.; Aly, T.A. and Abd-Elsayed, A.A. (2009): ophthalmic medicolegal cases in Upper Egypt. Inter. Archives Med., (2): 1-6. doi:10.1186/1755-7682-2-1

Weber, G.A. (1990): Nerve conduction studies and their clinical applications. Clin. Pediatr. Med. Surg., 7 (1): 151178

World Health Organization (WHO) (2018): Road traffic injuries report, 7 
December

2018.

https://www.who.int/news-room/fact$\underline{\text { sheets/detail/road-traffic-injuries }}$

Zanaty, A.W.A.; Badawy, S.M. and Kamel S.M. (2005): Medico-legal study of permanent infirmity in injured cases referred to Menoufyia University Hospital. M.D. Thesis. Faculty of Medince, Menoufyia University. 


\title{
الملخــص العربــى
}

\section{دراسة مستقبلية للوجهة الطبية الثرعية لحالات العاهة المستديمة التي تم فحصها بمنطقة

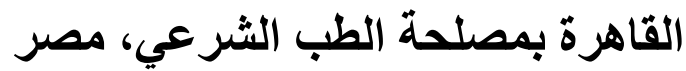

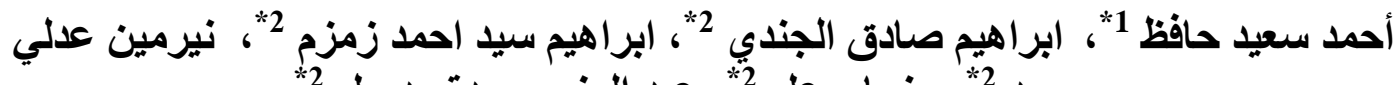

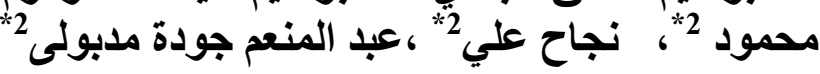 \\ 1 مصلحة الطب الثرعي بالقاهرة، وزارة العدل، مصر. \\ 2قسم الطب الشرعي و السموم الأكلينيكية، كلية الطب البشري البرة - جامعة بنها، مصرل مدر.
}

تعرف العاهة المستديمة بانها تحديد في وظيفة عضو ما أو فقده مما يحد من قدر ات المصاب على أداء انشطتة

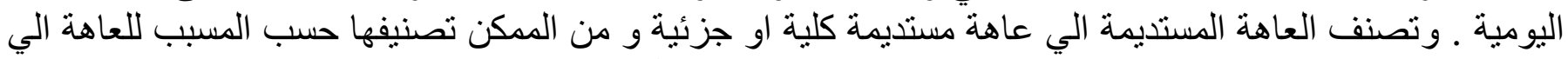

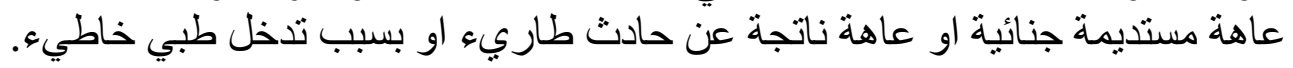
أجريت الدراسة الحالية على 150 حالة مصابة بعاهة مستديمة و و التى تم استقبالها بمنطقة القاهرة الطبية

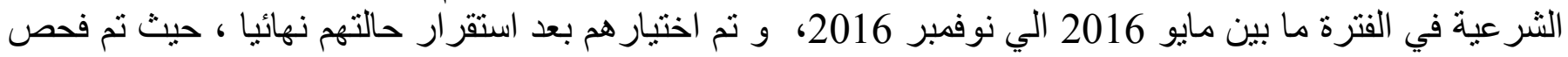
الحالات إكلينيكيا ودونت جميع البيانات في استمارة خاصة لكل مريض و اجريت لكل مصاب الفحوصات الطبية الازمة لحالته.

اسفرت الدر اسة الي ان نسبة حالات الذكور المصابة بعاهة مستديمة كانت 83.4 \% \% و نسبة حالات الاناث

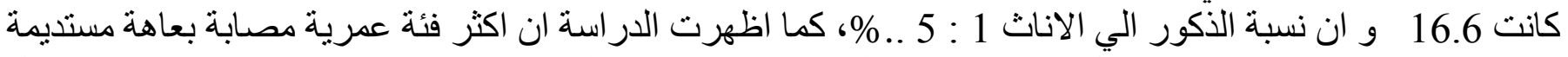

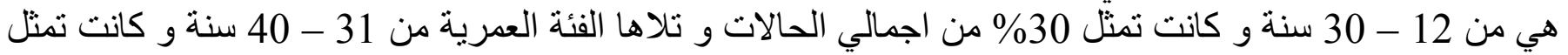

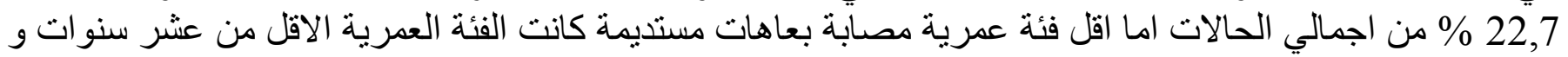
كانت تمثل 2,7 \% \% من اجمالي الحالات. اظهرت الدر اسة ان الحالات القادمة من المناطق الريفية مساوية تقريبا للحالات التي تقطن المناطق الحضرية ،

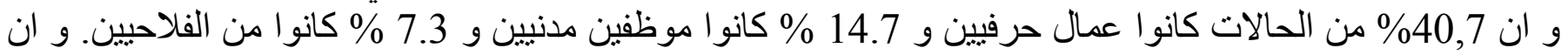

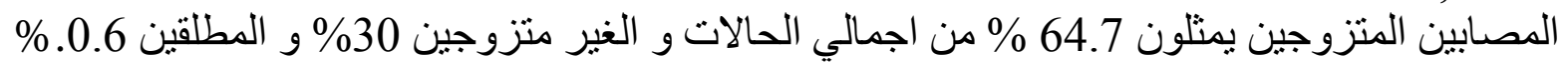

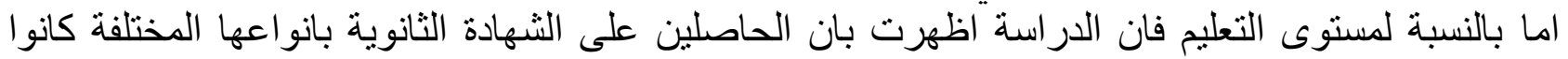

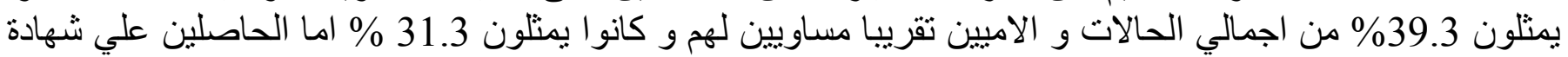
جامعية فكانوا يمثلون 13.3\% من من اجمالي الحالات. و قد تبين من الدراسة ان اكثر الاماكن التي اصيبت و نتج عنها عاهة مستديمة هي الاطر اف السفلية و التي

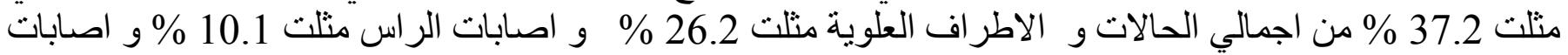

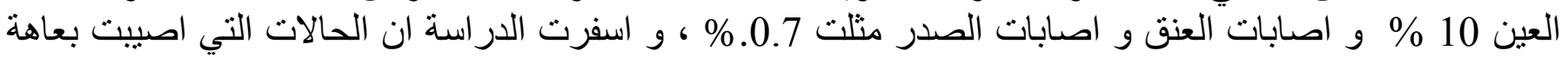

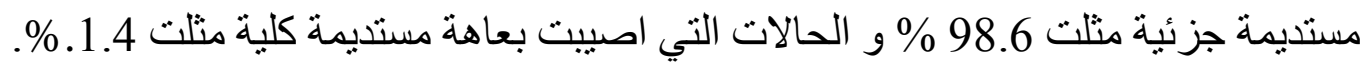

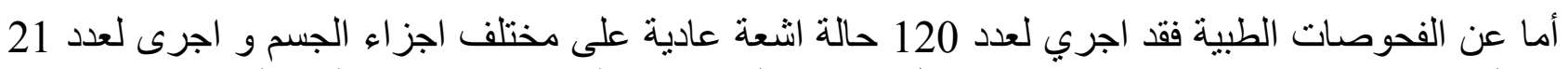

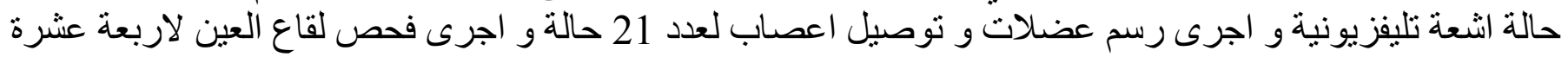

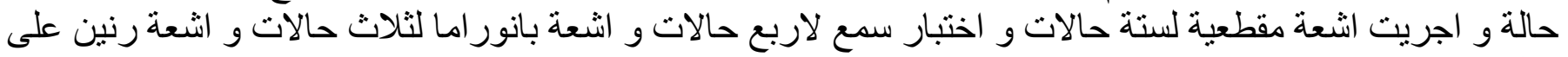
حالثين.

وقد أثبتت الدر اسة ان غالبية الحالات المصابة بعاهات مستديمة كانت بسبب حادث عارض و مثلت 51.3 \%

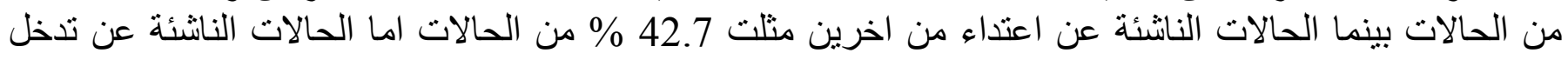

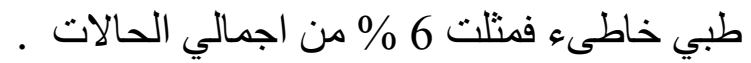


كما اثبتت الدر اسة ان حو ادث الطرق كانت السبب الرئيسي في حدوث العاهات المستديمة و منلت 47.3 \% من من

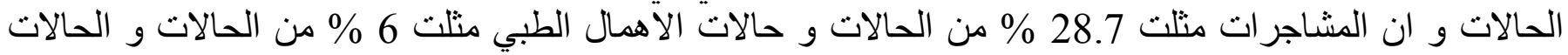

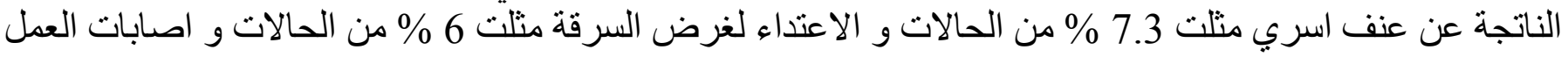
منلت 4 \% من الحالات و حالة و واحدة لادعاء تعذيب شرطة.

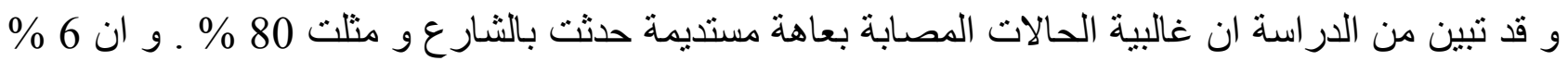
من الحالات حدثت بالمستشفيات و 6 \% من الحالات حدثت بمواقع العمل و 7.3 \% من الحالات حدثت بالمنازل و حالة

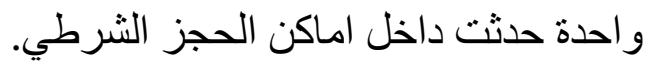

بينت الدر اسة ان 69.5 \% من الحالات حدثت بسبب الاصابة بجسم راض و 16.3 \% \% حدثت بسبب الة حادة و 9.3 \% حدثت بسبب طلق ناري و ( 2,1 \% \% \% ) من الحالات حدثت بسبب حرق ناري ، و ( 1,4 \% \% ) مبنب حرق

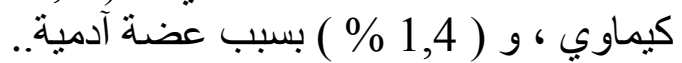
و اظهرت الدر اسة ان 49.6 \% \% من الحالات المصابة بعاهة مستديمة كانت تعانى من تحديد في حركة مفاصل

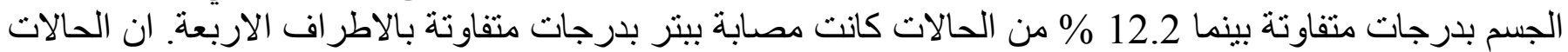

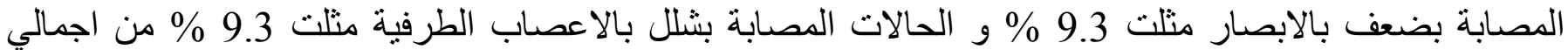
الحالات. و كانت 3.4 \% من الحالات مصابة بكسر مصاحب بفقد عظمي بالجمجمة و 1.3 \% من الحالات مصابة بشلل نصفي.

وقد عقدت الدر اسة الحالية مقارنة بين بعض الإرشادات المحلية (الجدول المصري) والإرشادات الدولية (جدول

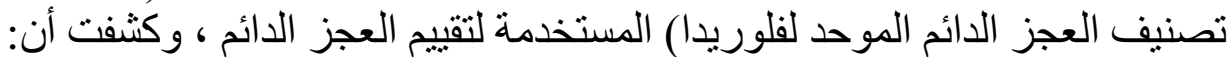

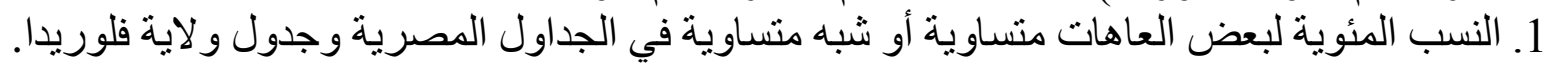

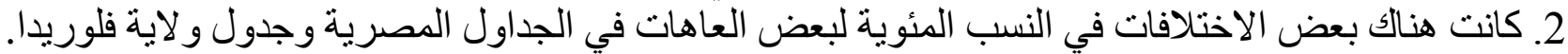
3. هنالك بعض العاهات التي تم تقييمها في جدول و لاية فلوريدا ولكن لم يتم تقييمها في الجداول المصدرية. 